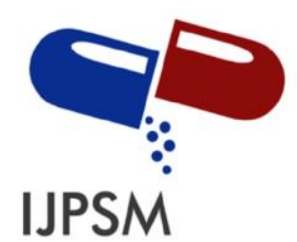

Kamelia Ramadaini et al, Int. Journal of Pharmaceutical Sciences and Medicine (IJPSM),

Vol.5 Issue. 12, December- 2020, pg. 35-45

ISSN: 2519-9889

Impact Factor: 3.426

\title{
Overview of Pharmacology and Product Development of Lime (Citrus aurantifolia) Rind
}

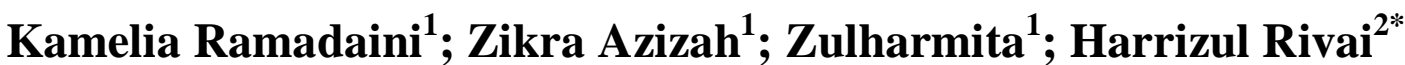 \\ ${ }^{1}$ College of Pharmacy (STIFARM), Jl. Raya Siteba Kurao Pagang, Padang 25147, Indonesia \\ ${ }^{2}$ Faculty of Pharmacy, Andalas University, Limau Manih Campus, Padang 25163, Indonesia \\ *Email: harrizul@yahoo.co.id; harrizul@ phar.unand.ac.id; kameliaramadaini23@yahoo.com
}

DOI: 10.47760/ijpsm.2020.v05i12.007

\begin{abstract}
Lime (Citrus aurantifolia) has many benefits for the human body because it contains several phytochemical compounds, namely alkaloids, flavonoids, steroids, and triterpenoids, saponins, tannins, and phenolics. However, many Indonesian people do not know that not only lime fruit has many benefits; the lime peel also has many benefits for the body. This review provides knowledge about the pharmacological activity and development of pharmaceutical products from the lime peel. The keywords Citrus aurantifolia, botany, phytochemical, pharmacology, and product development were searched until November 30, 2020, from journals that can be accessed in databases such as Google Scholar, Science Direct, Scopus, EBSCO, Medline, PubMed, Embase, and other databases. The results showed that this plant has various pharmacological properties such as anticancer, traumatic ulcer medication, tyrosinase inhibitor, antibacterial, and antifungal. The development of pharmaceutical products from the lime peel is for mosquito repellents, hand sanitizers, gel products, and chitosan nanoparticles. In conclusion, Citrus aurantifolia has various pharmacological properties and plays a vital role in human health; therefore, it can be used to produce drugs and cosmetics in the future.
\end{abstract}

Keywords: Citrus aurantifolia, lime peel, pharmacological review, product development

\section{Introduction}

Lime (Citrus aurantifolia; Family: Rutaceae) is a type of plant that belongs to the citrus tribe. Lime spread in Asia and Central America. Lime is also known as orange pecel.[1] Lime trees can reach 3-6 meters high, branched and thorny, oval leaves, small, winged petiole. Inflorescences emerge from the axillary leaves and small, white, fragrant flowers. The fruit is round to ovate, green to yellow, and the skin is thin and contains many essential oils (Figure 1).[2] Greenish white flesh, very acidic, includes lots of vitamin C and citric acid. The seeds are many, small, poly-embryonic (Figure 2).[3] In Indonesia, lime can live in the lowlands to an altitude of $1000 \mathrm{~m}$ above sea level. It grows well in alkaline soils, in places exposed to direct sunlightpropagation by seed, grafting, or grafting. The fruit is used to make drinks, cough medicine, and food flavoring and is often used to remove rust and wash hair.[1] 


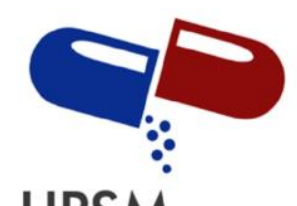

\section{IJPSM}

Kamelia Ramadaini et al, Int. Journal of Pharmaceutical Sciences and Medicine (IJPSM),

Vol.5 Issue. 12, December- 2020, pg. 35-45

ISSN: 2519-9889

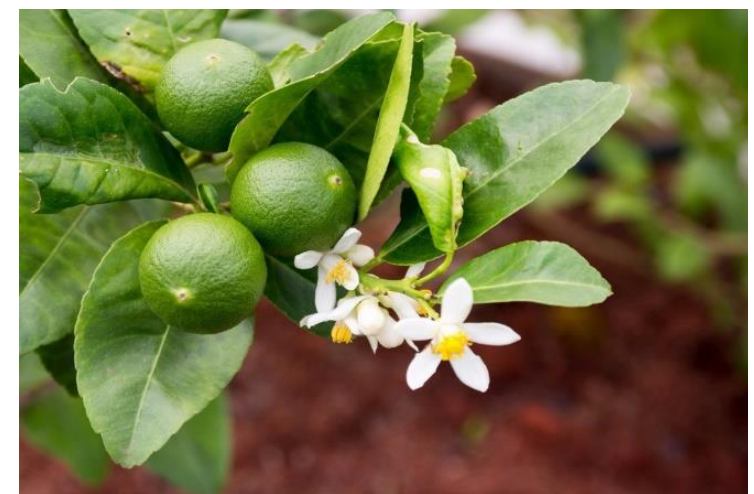

Impact Factor: 3.426

Figure 1. Lime plant morphology (Citrus aurantifolia)

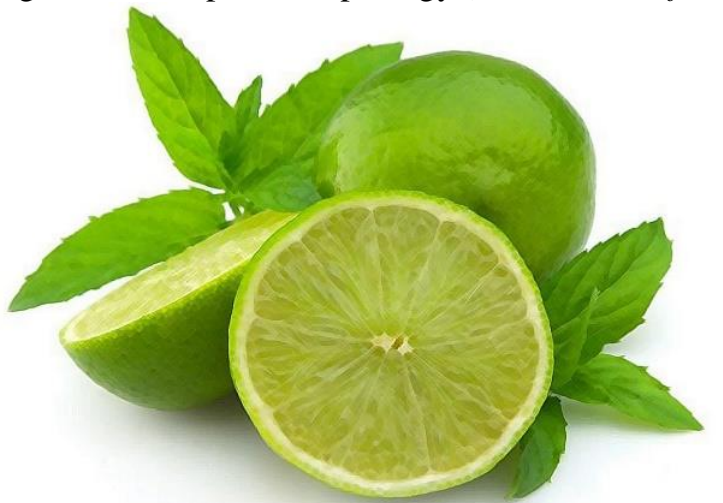

Figure 2. Lime fruit (Citrus aurantifolia)

\subsection{Scientific classification}

Scientifically, lime is classified as follows:[1]

Division: Tracheophyta

Superdivision: Spermatophytina

Clade: Angiosperms

Clade: Mesangiosperms

Clade: Eucods

Clade: Core Eucods

Clade: Superosids

Clade: Rosids

Clade: Malvids

Order: Sapindales

Family: Rutaceae

Superfamily: Aurantioideae

Tribus: Citrae

Genus: Citrus

Species: Citrus x aurantifolia

\subsection{Benefits of lime}

Traditionally, lime can be used for health and beauty as follows:[1]

- Hemorrhoid

- Tonsils 


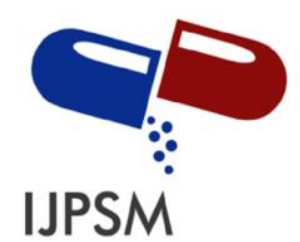

Kamelia Ramadaini et al, Int. Journal of Pharmaceutical Sciences and Medicine (IJPSM),

Vol.5 Issue. 12, December- 2020, pg. 35-45

ISSN: 2519-9889

Impact Factor: 3.426

- Toothache

- Cough

- Cough with phlegm

- Body odor

- Kidney stones

- Diphtheria

- Fever

- Irregular Menstruation

- After Childbirth

- Acne

- Prevents Hair Loss or Dandruff

- Thickens hair

- Quit Smoking Habit

- Vertigo

- Sore throat

- Mucus in the throat

- Ringworm or Panu

- Fever/Heat During Malaria

- Sore

- Slimming

- Increase Stamina

- High blood pressure

- Helps in The Removal of Dead Skin Cells

- Helps Clean Blackheads

- Make Your Face Healthier and Shine

\section{Research Methods}

\subsection{Data Collection}

In compiling this review article, the technique used is to use literature studies in primary data or official books and international journals in the last ten years (2010-2020). In making this review article, search for data using online media with keywords is Citrus aurantifolia, lime peel, phytochemicals, pharmacological activity, and product development. Search for the primary references used in this review article through trusted websites such as ScienceDirect, ResearchGate, NCBI, Google Scholar, and other published and trustworthy journals.

\section{Phytochemical Content}

Lime (Citrus aurantifolia) contains several phytochemical compounds, namely alkaloids, flavonoids, steroids, triterpenoids, saponins, tannins, and phenolics, which can inhibit bacterial growth.[4] The higher flavonoid content of lime is the skin, including the mesocarp, epicarp, and segment layers. Lime peels contain abundant amounts of apigenin (Figure 3), routine (Figure 4), quercetin (Figure 5), and kaempferol (Figure 6).[5] Lime peel can treat chronic inflammatory diseases such as acne vulgaris, which is made in the preparation of chitosan nanoparticles.[13] 


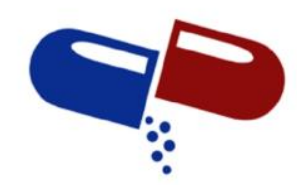

\section{IJPSM}

Kamelia Ramadaini et al, Int. Journal of Pharmaceutical Sciences and Medicine (IJPSM),

Vol.5 Issue. 12, December- 2020, pg. 35-45

ISSN: 2519-9889

Impact Factor: 3.426

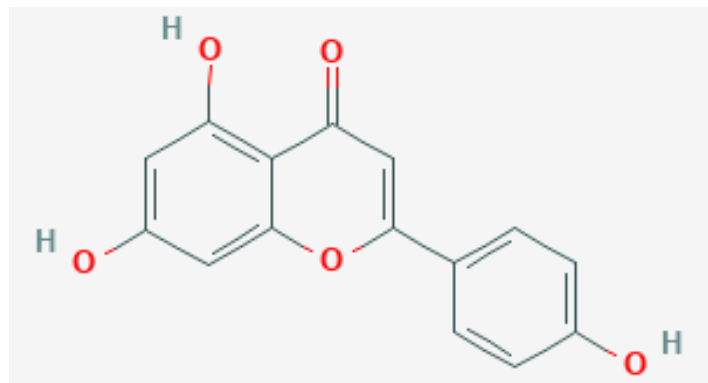

Figure 3. Apigenin structure. [6]

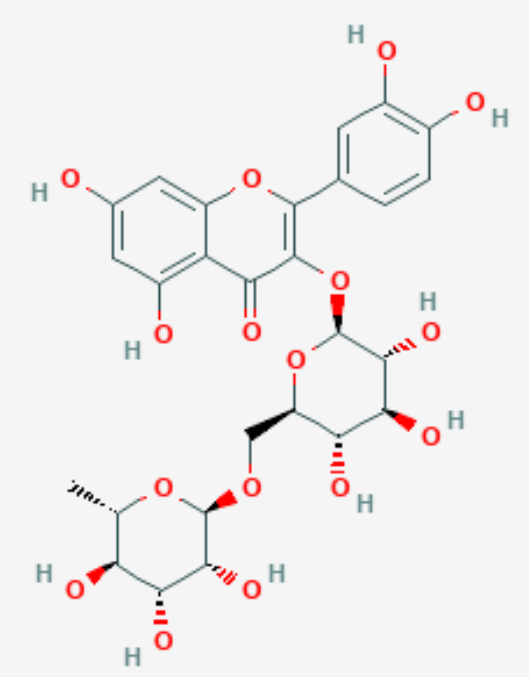

Figure 4. Rutin structure.[7]

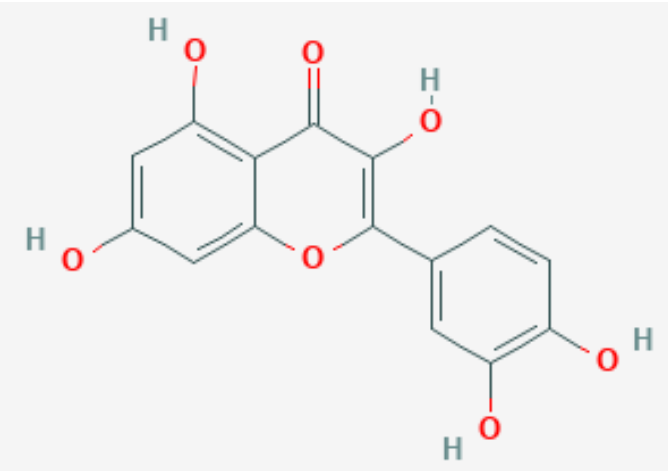

Figure 5. Quercetin structure.[8] 


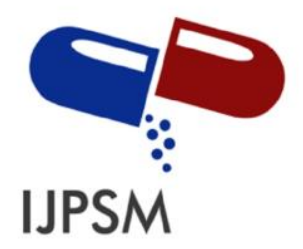

Kamelia Ramadaini et al, Int. Journal of Pharmaceutical Sciences and Medicine (IJPSM), Vol.5 Issue. 12, December- 2020, pg. 35-45

ISSN: 2519-9889<smiles>O=c1c(O)c(-c2ccc(O)cc2)oc2cc(O)cc(O)c12</smiles>
Impact Factor: 3.426

Figure 6. Structure of kaempferol.[9]

The purification of hesperidin is carried out using Mexican lime peels. Lime peel is rich in flavonoids hesperidin, which has bioactivity in cardiovascular disease and cancer. Hesperidin extraction used a variety of solvents and solid-solvent ratios. Furthermore, the purification process uses adsorption resin through a static test to determine the adsorption efficiency with two resins (FPX66, EXA118), then packed in a bottle and put $80 \mathrm{~mL}$ of resin heated at $25^{\circ} \mathrm{C}$. Laboratory results showed the best conditions were solid-solvent ratio 0.33 $\mathrm{g} / \mathrm{mL}$ and $60 \%$ ethanol. The hesperidin content of the extract was $0.0303 \mathrm{mg} / \mathrm{mL}$. Through the static test, a higher adsorption efficiency was achieved with EXA-118 resin and diluted extract (4: 6 ratio with 10\% dimethylsulfoxide (DMSO). Then, the column-packed purification process of the light extract (hesperidin concentration $0.109 \mathrm{mg} / \mathrm{mL}$ ) had an average recovery efficiency of nearly $90 \%$. The purification process of hesperidin from Mexican lime peel consists of hydroalcoholic extraction and purification using the EXA-118 resin packaging. It provides an advantage over traditional alkaline processes, as it does not use acids and bases, which are high environmental and economic costs. It also has the same or higher recovery efficiency than the given alkaline method. Therefore, it is an excellent alternative for industrial applications for the purification of hesperidin from Mexican lime peels. The results of the cleansing of hesperidin are shown in Table 1 below.[17]

Table 1. Total levels of hesperidin in Mexican lime peels.[17]

\begin{tabular}{|c|c|c|}
\hline Parameter & Average value & $\begin{array}{c}\text { Coefficient of variation } \\
(\%)\end{array}$ \\
\hline Extract concentration $(\mathrm{mg} / \mathrm{mL})$ & $0.078 \pm 0.021$ & $33.4 \%$ \\
\hline Concentration of dried fruit peels $(\mathrm{mg} / \mathrm{g})$ & $3.528 \pm 0.962$ & $33.4 \%$ \\
\hline Water content $(\%)$ & $81.57 \pm 1.92$ & $2.9 \%$ \\
\hline Concentration of fresh fruit peels $(\mathrm{mg} / \mathrm{g})$ & $0.653 \pm 0.208$ & $39.1 \%$ \\
\hline
\end{tabular}

There are two procedures for purifying raw hesperidin on lime peels:[18]

Procedure A: Crude hesperidin is added to dimethylformamide ( $7 \mathrm{~mL} / \mathrm{g}$ syrup) and then heated to $60{ }^{\circ} \mathrm{C}$, then a little acetic acid is added. Filter using a funnel, diluted with water, and let stand for 4 hours until it crystallizes and filters the crystals again.

Procedure B: Raw hesperidin is added to chloroform. The white crystals of hesperidin were filtered using a funnel, and pure hesperidin was obtained with a melting point of $240-253^{\circ} \mathrm{C}$. 


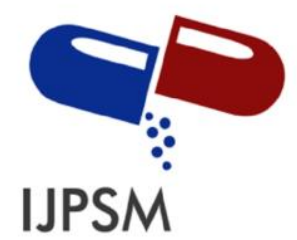

Kamelia Ramadaini et al, Int. Journal of Pharmaceutical Sciences and Medicine (IJPSM), Vol.5 Issue. 12, December- 2020, pg. 35-45

ISSN: 2519-9889

Impact Factor: 3.426

\section{Pharmacological Activity}

The pharmacological activities of the lime rind extract are shown in Table 2 below.

Table 2. Some of the pharmacological activities of lime peel extract

\begin{tabular}{|c|c|c|c|c|}
\hline $\begin{array}{c}\text { Pharmacological } \\
\text { Activities }\end{array}$ & Solvent & $\begin{array}{c}\text { Extraction } \\
\text { method }\end{array}$ & Ref. \\
\hline $\begin{array}{c}\text { Anticancer } \\
\text { activity }\end{array}$ & - & - & - & {$[10]$} \\
\hline $\begin{array}{c}\text { Nephroprotective } \\
\text { activity }\end{array}$ & Ethanol & - & In vivo & {$[11]$} \\
\hline $\begin{array}{c}\text { Traumatic Ulcer } \\
\text { Medication }\end{array}$ & Ethanol 70\% & Maceration & $\begin{array}{c}\text { Determination test, Kruskal- } \\
\text { Wallis non-parametric test, Mann- } \\
\text { Whitney Post Hoc test }\end{array}$ & {$[12]$} \\
\hline $\begin{array}{c}\text { Tyrosinase } \\
\text { inhibitors }\end{array}$ & $\begin{array}{c}\text { Ethanol 96\%, } \\
\text { distilled water }\end{array}$ & Maceration & $\begin{array}{c}\text { In vitro test, multi-well plate } \\
\text { reader (ELISA) test }\end{array}$ & {$[13],[14]$} \\
\hline $\begin{array}{c}\text { Antibacterial } \\
\text { endophytic fungi }\end{array}$ & $\begin{array}{c}\text { Ethanol 70\%, } \\
\text { distilled water, } \\
\text { API }\end{array}$ & - & Disc paper method & {$[15],[16]$} \\
\hline
\end{tabular}

\subsection{Anticancer Activity}

Although lime fruit is a common fruit and easy to use in daily consumption, it contains many beneficial substances to human health. It may be a miracle fruit. Phytochemicals such as alkaloids, carotenoids, coumarin, essential oils, flavonoids, phenolic acids, and triterpenoids are abundantly present in oranges. All of these substances have various pharmacological properties, especially anticancer. C. aurantifolia was studied for its effect on carcinogenesis by mechanisms such as stopping the mobility of cancer cells in the circulatory system; thus, it inhibits metastasis, inhibits angiogenesis, induces tumor suppressor genes and apoptosis.[10]

\subsection{Nephroprotective Activity}

The ethanol extract of lime peel (Citrus aurantifolia) has a nephroprotective effect on the histopathological picture of Sprague Dawley rats' kidney induced by cisplatin. This effect is indicated by differences in the degree of necrosis of renal tubular cells. The orange peel extract shows good free radical antioxidant potential through its flavonoid content. Flavonoids such as quercetin, hesperidin, and naringenin show good protective activity against the kidneys. It was also mentioned that the ethanol extract of lime peel contains naringin compounds, which are known to have anti-carcinogenetic and anti-tumor properties. Cancer is a type of noncommunicable disease. Cancer experiences uncontrolled cell or tissue growth continues to grow, multiply, and cannot die. Cisplatin is the primary chemotherapy drug that has a cytotoxic effect on cancer cells. Cisplatin not only affects cancer cells but also has a side effect of nephrotoxicity to the kidneys. Cisplatin causes nephrotoxicity through the mechanisms of oxidative stress, apoptosis, inflammation, and fibrogenesis. Mice that received cisplatin injection $2 \mathrm{mg} / \mathrm{kg} / \mathrm{BW}$ once a week for seven weeks showed progressive development of fibrotic lesions in corticomedullary function at the beginning of the first week and peaked at week five. All damage incurred was corrected during the 19 weeks follow-up period following discontinuation of cisplatin administration by reducing fibrotic tissue by alternating renal tubular regeneration. The healing process is accompanied by creatinine and blood urea nitrogen (BUN) levels in the blood. Macrophages play a role in renal interstitial fibrosis through the production of TGF-1 and TNF.[11]

\subsection{Traumatic Ulcer Medication}

This study was to determine the effect and effective concentration of lime peel extract on the healing of traumatic ulcers. One alternative treatment is the ethanol extract of lime peel. The ethanol extract of lime peel results from the maceration of the lime peel, which has anti-inflammatory properties and helps the wound healing process. Traumatic ulcers are inflammation of the oral mucosa caused by traumatic injuries such as 


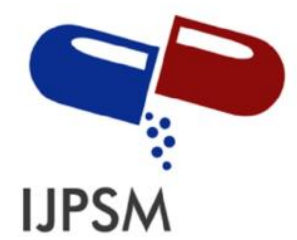

\section{Kamelia Ramadaini et al, Int. Journal of Pharmaceutical Sciences and Medicine (IJPSM), Vol.5 Issue. 12, December- 2020, pg. 35-45}

ISSN: 2519-9889

Impact Factor: 3.426

thermal, chemical, radiation, mechanical, and practical injuries. A pure laboratory experimental with posttest only control group design was used in this study. Twenty-four Wistar rats were given one drop of Perhidrol on the lower lip mucosa to form ulcerated lesions. Two drops of lime peel ethanol extract at concentrations of $6.25 \%, 12.5 \%, 25 \%$, and $50 \%$, distilled water as a negative control, and Aloiclair as a positive control were applied the same area twice a day. The final diameter of the ulcer was measured using a caliper on the fifth day. The results showed that the ethanol extract of lime peel improved the healing of traumatic ulcers with $p=$ 0.001 . The most effective concentration of lime peel ethanol extract is at a concentration of 25-50\%. Therefore, the ethanol extract of lime peel affects ulcer healing.[12]

\subsection{Tyrosinase Inhibitors}

This study tested the potential of the lime peel as a tyrosinase inhibitor. Tyrosinase enzymes help in the process of forming melanin compounds (melanogenesis). Tyrosinase enzymes catalyze two main reactions in melanin biosynthesis, namely L-tyrosine's hydroxylation to L-dopa and the oxidation of L-dopa to dopa quinone. Lime peel was extracted by maceration using ethanol $96 \%$ solvent. The result of maceration is the formation of yellow to red colors containing flavonoids. Calculate the total flavonoids by entering the absorbance value on the standard quercetin curve with the curve equation, namely $\mathrm{y}=0.0706 \mathrm{x}-0.0465$, and the result is $0.667 \%$ $\mathrm{w} / \mathrm{w} \mathrm{mg} / \mathrm{kg}$. From this equation, the IC50 of lime peel is obtained, namely $42.11 \mathrm{mg} / \mathrm{mL}$. The IC50 value determines the level of lime peel extract as a tyrosinase inhibitor to inhibit melanin formation. Furthermore, the tyrosinase inhibition activity test was carried out using a microplate reader (ELISA) instrument with a value of IC50. Tests were carried out by diluting the extract at a concentration of $5 \mathrm{mg}, 10 \mathrm{mg}, 20 \mathrm{mg}, 30 \mathrm{mg}, 40 \mathrm{mg}$, and $50 \mathrm{mg}$. After that, the determination of IC50 by making the inhibitor concentration relationship curve, namely the sample (lime peel extract), is entered into the equation $y=85.929$ In (x) - 271.4. Tyrosinase plays a role in the melanogenesis process because tyrosinase has a copper $(\mathrm{Cu})$ group, which is the active site associated with the substrate for the melanin formation process. The IC50 value was $42.11 \mathrm{mg} / \mathrm{mL}$, which indicates that the lime peel extract can act as a tyrosinase inhibitor.[13] Lime peel has better tyrosinase enzyme inhibition than lime seeds.[14]

\subsection{Antibacterial Endophytic Fungi}

Lime peel was extracted with methanol and fractionated with ethyl acetate, $n$-hexane, and water. The extract was purified by chromatography technique. Spectrophotometric analyses, such as UV, NMR, IR, and MS, are used to characterize the structure of biologically active compounds. The results of isolation from lime peel obtained a monoterpenoid derivative combination with the formula $\mathrm{C}_{10} \mathrm{H}_{16} \mathrm{O}_{2}$. They got a minimum biofilm eradication concentration (MBEC) value of $34.75 \%$ for an induction time of 30 minutes. Antibacterials are obtained from monoterpenoids extracted from lime peel for the prevention of biofilm formation.[15]

Endophytic fungi are fungi that live in plant tissues and do not harm these plants. Endophytic fungi can produce compounds that have the potential as antibacterial. The method used is the disc paper method, which is done by sticking disc paper containing endophytic fungi supernatant on the media so that the combination has been smeared with the test bacteria. The results showed that two types of endophytic fungi were isolated from the lime peel, namely white and black fungus isolates. Both endophytic fungi have an antibacterial effect against the tested bacteria. However, type II endophytic fungi have a better antibacterial effect than type I endophytic fungi. The mean diameter of the inhibition zone was $1.76 \mathrm{~mm}$.[16] 


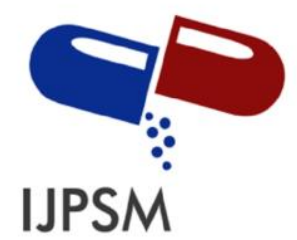

Kamelia Ramadaini et al, Int. Journal of Pharmaceutical Sciences and Medicine (IJPSM), Vol.5 Issue. 12, December- 2020, pg. 35-45

ISSN: 2519-9889

Impact Factor: 3.426

\section{Pharmaceutical Product Development}

Several pharmaceutical and cosmetic products have been developed from extracts of lime skin. The pharmaceutical and cosmetic products are presented in Table 3 below.

Table 3. Some pharmaceutical preparations from lime peel

\begin{tabular}{|c|c|c|c|c|}
\hline Preparation & Solvent & $\begin{array}{c}\text { Extraction } \\
\text { method }\end{array}$ & Resting & Ref. \\
\hline $\begin{array}{c}\text { Mosquito } \\
\text { repellent }\end{array}$ & Distilled water & Infusion & $\begin{array}{c}\text { Posttest only } \\
\text { group design }\end{array}$ & {$[19]$} \\
\hline Hand sanitizer & $\begin{array}{c}\text { Alcohol, glycerin, } \\
\text { triethanolamine }\end{array}$ & $\begin{array}{c}\text { Maceration } \\
\text { hom test, } \\
\text { hogeneity test, } \\
\text { secondary } \\
\text { metabolite test }\end{array}$ & [20], [21] \\
\hline $\begin{array}{c}\text { Anti-wrinkle } \\
\text { gel }\end{array}$ & Ethanol 96\% & Maceration & $\begin{array}{c}\text { DPPH, video } \\
\text { dermatoscopy test }\end{array}$ & {$[22],[23]$} \\
\hline $\begin{array}{c}\text { Chitosan } \\
\text { Nanoparticles }\end{array}$ & $\begin{array}{c}\text { Tween 80, } \\
\text { propylene glycol, } \\
\text { cetyl alcohol, } \\
\text { paraffin liquid }\end{array}$ & Distillation & In vivo & {$[24],[25]$} \\
\hline
\end{tabular}

\subsection{Mosquito Repellent}

Lime rind is washed using water, cut into small pieces, and then weighed as much as $10 \mathrm{~g}, 15 \mathrm{~g}, 20 \mathrm{~g}$, and $25 \mathrm{~g}$. Lime peel was put into each pan, and each added $100 \mathrm{~mL}$ of distilled water, heated over a water bath for 15 minutes, starting from a temperature of $90^{\circ} \mathrm{C}$ while stirring occasionally. The infusion is filtered using filter paper while hot, then added with hot distilled water until the infusion volume is $100 \mathrm{~mL}$-Dengue Hemorrhagic Fever (DHF) transmission to humans through the bite of a female Aedes aegypti mosquito. So far, people use chemical insecticides to prevent mosquito bites (repellent). Controlling the use of natural insecticides, one of which is the infusion of lime rind because it has essential oils that are not liked by mosquitoes or insects. This type of research is experimental with posttest only group design research design. The results showed that all concentrations of lime peel use showed insecticidal activity. A $25 \%$ lime rind infusion is proven to be more effective than a $10-20 \%$ concentration. It takes 60 minutes to give a $90 \%$ mortality rate. The positive control had a $100 \%$ mosquito mortality rate. Lime rind infusion has potential as a biocontrol.[19]

\subsection{Hand Sanitizer}

This research is an experimental study using lime peel extract samples and analyzing qualitative descriptive data. How to make lime peel extract is as follows; lime peel washed under running water, peeled and separated from its contents, then stored in the oven for one day at $50{ }^{\circ} \mathrm{C}$. The dried lime peel is blended until smooth, filtered, then macerated with ethanol for one day. Hand sanitizers are made in the following way: the maceration results have turned clear yellow and have separated the sediment. The yellow liquid is heated until it thickens and turns brown. Combine all ingredients such as carbopol, glycerin, triethanolamine (TEA), and polyethylene glycol (PEG) until the result forms a gel.[20]

Based on the results obtained, this hand sanitizer from lime peel extract contains secondary metabolites beneficial for skin health and moisture, $\mathrm{pH} 7$ (neutral), good organoleptic test, yellow color, and distinctive odor, an adequate level of homogeneity of hand sanitizer gel.[20] The effect of a hand sanitizer depends on ingredients such as 60-95\% alcohol. Alcohol can usually damage the skin with frequent use. If you are at home, you shouldn't need to use a hand sanitizer because there are soap and water. However, if you are outside the house, you can use a hand sanitizer.[21] 


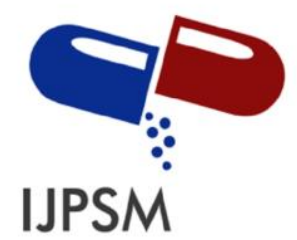

Kamelia Ramadaini et al, Int. Journal of Pharmaceutical Sciences and Medicine (IJPSM), Vol.5 Issue. 12, December- 2020, pg. 35-45

ISSN: 2519-9889

Impact Factor: 3.426

\subsection{Anti-Wrinkle Gel}

The lime peel is dried, then mashed to become a simplicia powder and weighed. The extraction process was carried out by the maceration method using $96 \%$ ethanol as a solvent. Simplicia was soaked in solvent for $3 \mathrm{x}$ 24 hours. Then the filtrate is concentrated using a rotary evaporator to obtain a thick extract. Gel with antioxidant content is one of the preparations used as cosmetics in treating faces. Many antioxidants are found in nature, one of which has a high antioxidant content is lime.[22] Lime peel can be treated with 1, 2, and 3\% $\mathrm{NaCl}$ for 30 minutes and stored overnight. Washed well before pectin extraction.[23] This study is a real experiment to calculate the number of wrinkles on the skin using the video dermatoscopy method. For three gel preparations, the ethanol extract concentration of lime peel was made in various concentrations of $0.6 \%$ for formula $1,1.2 \%$ for formula 2 , and $1.8 \%$ for formula 3 . The test results were based on a physical stability test. Formula 1, 2, and 3 are stable during storage. Meanwhile, based on the antioxidant activity test results, the preparation with the best antioxidant is formula 3 with an IC50 value of $68.85 \mathrm{ppm}$, which is included in the potent antioxidant category. The anti-wrinkle activity test results showed that the best formula, namely formula 3 , can reduce the number of wrinkles on the respondent's skin, with a decrease in the entropy value of 0.00087.[22]

\subsection{Chitosan Nanoparticles}

This study was conducted to evaluate and compare the effectiveness of the essential oil of lime peel encapsulated and not encapsulated into chitosan nanoparticles in inhibiting $P$. acnes. The method used is the synthesis method of lime peel essential oil, encapsulated into chitosan nanoparticles. The inhibition zone of $P$. acnes is known as a non-growth area after exposure to lime peel essential oil, which is encapsulated into chitosan nanoparticles. Acne vulgaris (AV) is a chronic inflammatory disease that affects $85 \%$ of adolescents. The pathogenesis of acne vulgaris (AV) includes hypercolonization of the pilosebasea gland by P. acnes. Chitosan is a natural ingredient produced from the deacetylation of chitin and the crustacean exoskeleton. Chitosan is widely explored in the biomedical field as an active agent or drug carrier. The results showed that the essential oil of lime peel with a concentration of $2.5 \%$ into the chitosan nanoparticles using the polymer chitosan-sodium tripolyphosphate with the ionic gelation method and larger P. acnes and the chitosan nanoparticle formula leading to an inhibition zone with a diameter of $20.61 \mathrm{~mm}$. In contrast, the nonencapsulated procedure only produces an inhibition zone of 10-20 mm. It can be concluded that the encapsulation formulation of chitosan nanoparticles has increased.[24] Chitosan nanoparticles were prepared using the ionic gelation method based on the ionic interaction between the hostile amino groups in chitosan and the negatively charged polyanions, namely Na-TPP.[25]

\section{Conclusion}

Based on the description above, it can be concluded that lime peel (Citrus aurantifolia) contains several chemical compounds, especially flavonoids and essential oils. This chemical content has several pharmacological activities such as anticancer, traumatic ulcer medication, tyrosinase inhibitor, antibacterial, and antifungal. Lime peel extract can be made in several pharmaceutical and beauty preparations such as mosquito repellent, hand sanitizer, anti-wrinkle gel, and chitosan nanoparticles.

\section{References}

[1]. https://id.m.wikipedia.org/wiki/Jeruk_nipis

[2]. https://cdn.shopify.com/s/files/1/1217/9420/products/Fotolia_81592947_Subscription_Monthly_M_grande.jpg?v=151 2602980

[3]. https://assets.pikiran-rakyat.com/crop/0x0:0x0/x/photo/2020/02/08/1187444172.jpg

[4]. Parama PW, Sukrama ID, Handoko SA. Uji efektifitas antibakteri ekstrak buah jeruk nipis (Citrus aurantifolia) terhadap pertumbuhan Streptococcus mutans in vitro. Bali Dental Journal. 2019 May 9;3(1):45-52. 


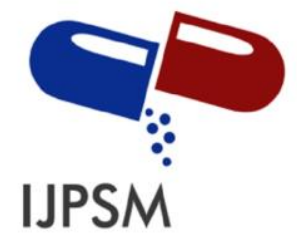

\section{Kamelia Ramadaini et al, Int. Journal of Pharmaceutical Sciences and Medicine (IJPSM), Vol.5 Issue. 12, December- 2020, pg. 35-45}

ISSN: 2519-9889

Impact Factor: 3.426

[5]. Loizzo MR, Tundis R, Bonesi M, Menichini F, De Luca D, Colica C, Menichini F. Evaluation of Citrus aurantifolia peel and leaves extracts for their chemical composition, antioxidant and anti- cholinesterase activities. Journal of the Science of Food and Agriculture. 2012 Dec;92(15):2960-7.

[6]. National Center for Biotechnology Information (2020). PubChem Compound Summary for CID 5280443, Apigenin. Retrieved October 21, 2020, from https://pubchem.ncbi.nlm.nih.gov/compound/Apigenin.

[7]. National Center for Biotechnology Information (2020). PubChem Compound Summary for CID 5280805, Rutin. Retrieved October 21, 2020, from https://pubchem.ncbi.nlm.nih.gov/compound/Rutin.

[8]. National Center for Biotechnology Information (2020). PubChem Compound Summary for CID 5280343, Quercetin. Retrieved October 21, 2020, from https://pubchem.ncbi.nlm.nih.gov/compound/Quercetin.

[9]. National Center for Biotechnology Information (2020). PubChem Compound Summary for CID 5280863, Kaempferol. Retrieved October 21, 2020, from https://pubchem.ncbi.nlm.nih.gov/compound/Kaempferol.

[10]. Narang N, Jiraungkoorskul W. Anticancer activity of key lime, Citrus aurantifolia. Pharmacognosy reviews. 2016 $\mathrm{Jul} ; 10(20): 118$.

[11]. Kurniandari N, Susantiningsih T. Efek Ekstrak Etanol Kulit Jeruk Nipis (Citrus aurantifolia) sebagai Senyawa Nefroprotektor terhadap Gambaran Histopatologis Ginjal yang Diinduksi Cisplatin. Jurnal Majority. 2015 Dec 1;4(9):140-3.

[12].Wardani RP, Kholifa M, Yuletnawati SE. Pengaruh Ekstrak Etanol Kulit Jeruk Nipis (Citrus aurantifolia (Christm.) Swingle) Terhadap Penyembuhan Ulkus Traumatik Pada Rattus norvegicus Strain Wistar. JIKG (Jurnal Ilmu Kedokteran Gigi). 2017 Jan 1;1(1):23-7.

[13].Hindun S, Rusdiana T, Abdasah M, Hindritiani R. Potensi Limbah Kulit Jeruk Nipis (Citrus Auronfolia) sebagai Inhibitor Tirosinase. Indonesian Journal of Pharmaceutical Science and Technology. 2017 Oct 25;4(2):64-9.

[14]. Mirah L, Girsang E, Nasution AN, Lister IN. Antioxidant and Tyrosinase Enzyme Inhibition Activity of Lime Peel and Seed Ethanol Extract. American Scientific Research Journal for Engineering, Technology, and Sciences (ASRJETS). 2020 January 22;63(1):87-93.

[15].Jeffreya J, Sudigdoadib S, Kurniac D, Satarid MH. A Monoterpenoid Isolated from Citrus Aurantifolia Peel and Its Potential as An Antibacterial for The Inhibition and Eradication of Streptococcus Mutans Biofilm. Systematic Reviews in Pharmacy. 2020;11(6):1205-10.

[16]. Setiawan MA, Hasnawati H, Sernita S, Sulistia L. Uji Daya Hambat Antibakteri Fungi Endofit Kulit Jeruk Nipis (Citrus aurantifolia) Terhadap Bakteri Staphylococcus aureus. Jurnal Sains Farmasi \& Klinis. 2016 Dec 28;3(1):14-8.

[17].Padilla de la Rosa JD, Ruiz-Palomino P, Arriola-Guevara E, García-Fajardo J, Sandoval G, Guatemala-Morales GM. A Green process for the extraction and purification of hesperidin from mexican lime peel (Citrus aurantifolia Swingle) that is extendible to the citrus genus. Processes. 2018 Dec;6(12):266.

[18].Lahmer N, Belboukhari N, Cheriti A, Sekkoum K. Hesperidin and hesperetin preparation and purification from Citrus sinensis peels. Der Pharma Chemica. 2015;7(2):1-4.

[19]. Aritonang BN, Carolina K. Uji Efektivitas Infusa Kulit Buah Jeruk Nipis (Citrus aurantifolia) dengan Pembanding Spray Anti Nyamuk Bermerk Terhadap Nyamuk Aedes Aegypti. Jurnal Sains dan Teknologi Laboratorium Medik. 2017;2(1):14-8.

[20]. Aprilia S, Yanti W. Pemanfaatan Kulit Jeruk Nipis Sebagai Alternatif Hand Sanitizer. Proceeding IAIN Batus angkar. 2020 May 29;1(3):227-32.

[21]. Himabindu CS, Tanish BT, Kumari NP, Nayab SN. Hand sanitizers: is over usage harmful. World Journal of Current Medical and Pharmaceutical Research. 2020 Sep 9:296-300.

[22]. Auliasari N, Najihudin A, Restuny E. Pemanfaatan Limbah Kulit Jeruk Nipis (Citrus aurantifolia) dalam Formula Sediaan Gel Sebagai Anti-Wrinkle. Jurnal Ilmiah Farmako Bahari. 2019 Nov 14;10(2):171-82.

[23]. Wijayadi LJ, Rusli TR. Encapsulated Lime Peel Essential Oil (Citrus hystrix) Into Chitosan Nanoparticle: New Entity to Enhanced Effectivity Against Propionibacterium Acne in Vitro. In IOP Conference Series: Materials Science and Engineering 2020 July 1 (Vol. 852, No. 1, p. 012016). IOP Publishing.

[24]. Raj AA, Ranganathan TV. Extraction of Pectin from Different Fruit Wastes due to the Quality Upgradation of Jellies Preparation-Review. 1: 553 DOI: 10.4172/scientific reports. 553 Page 2 of 3 Volume 1・ Issue $12 \bullet 2012$ pomelo peel exhibited slow setting, whereas passion fruit rind and lime peel jellies exhibited very fast setting nature and achieved proper set within 20 minutes. Pumello peel attained fast setting. 2012.

[25]. Tiyaboonchai W. Chitosan nanoparticles: a promising system for drug delivery. Naresuan University Journal: Science and Technology (NUJST). 2013 August 1;11(3):51-66. 


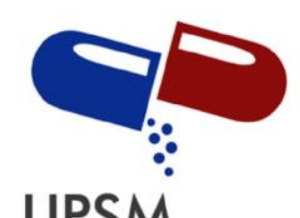

Kamelia Ramadaini et al, Int. Journal of Pharmaceutical Sciences and Medicine (IJPSM),

Vol.5 Issue. 12, December- 2020, pg. 35-45

ISSN: 2519-9889

Impact Factor: 3.426

\section{A Brief Author Biography}

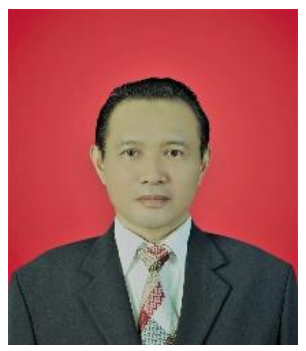

Harrizul Rivai - The Author obtained a bachelor's degree in pharmacy from the Department of Pharmacy, Faculty of Mathematics and Natural Sciences, Padjajaran University, Bandung, a master's degree in science from the Bandung Institute of Technology, and a doctorate from the Department of Chemistry, Faculty of Mathematics and Natural Sciences, Andalas University, Padang. Now the Author is a professor and researcher at the Faculty of Pharmacy, Andalas University, Padang. The Author wrote the book "Principles of Chemical Examination" and translated the book "Pharmaceutical Statistics." The Author has also written articles in various international journals in multiple science fields, such as chemistry, biology, and pharmacy. 